\title{
COM \\ Communicating with Coastal Decision-Makers and Environmental Educators via Sea Level Rise Decision-Support Tools
}

\author{
Denise E. DeLorme, Sonia H. Stephens, Scott C. Hagen \\ and Matthew V. Bilskie
}

\begin{abstract}
Communicating about environmental risks requires understanding and addressing stakeholder needs, perspectives, and anticipated uses for communication products and decision-support tools. This paper demonstrates how long-term dialogue between scientists and stakeholders can be facilitated by repeated stakeholder focus groups. We describe a dialogic process for developing science-based decision-support tools as part of a larger sea level rise research project in the Gulf of Mexico. We demonstrate how focus groups can be used effectively in tool development, discuss how stakeholders plan to use tools for decision-making and broader public outreach, and describe features that stakeholders perceive would make products more usable.
\end{abstract}

Keywords

DOI

Introduction
Environmental communication; Risk communication; Social inclusion

https://doi.org/10.22323/2.17030203
Communication about climate change and its effects often requires tailoring efforts toward specific audiences - in particular, toward audiences that may have decision-making power over policy and mitigation options [Moser and Dilling, 2011]. To prepare for sea level rise (SLR), coastal stakeholders - including resource managers, community planners, public officials, and environmental educators need access to scientific information in readily-usable formats and channels [Tribbia and Moser, 2008]. While these stakeholder groups have diverse areas of expertise, they all have uses for information in specialized formats different from what many members of the lay public might require. For example, localized maps depicting various SLR scenarios may be used to support decision-making by resource managers or community planners, or serve as communication aids with which educators facilitate public discussions about risk.

The transition from useful to readily-usable information can be complex and requires careful communication efforts that are customized to specific audiences [Lemos, Kirchhoff and Ramprasad, 2012; Sheppard et al., 2011]. Such customized communication efforts occur within the broader context of a shift from a top-down, 
information-oriented "deficit" model of science communication towards dialogic and participatory communication models [National Academies of Sciences, Engineering, and Medicine, 2017]. In the latter approaches, the implications of scientific information (in the dialogic model) and the direction of scientific research (in the participatory model) are discussed and negotiated among scientists and audiences [Bucchi, 2008, pp. 75-76]. Dialogic and participatory models of science communication require both "strategic listening" to the information needs of audiences and "strategic organization" of communication teams comprised of subject-matter specialist scientists, social scientists, and science communication specialists [Pidgeon and Fischhoff, 2011]. Moreover, dialogic communication can facilitate interaction among members of the public as well as between laypeople and scientists [Frazier, Wood and Yarnal, 2010; Leon et al., 2015]. In the context of SLR, audience engagement often involves data selection and visualization as well as identifying key stakeholder groups for dialogue efforts [Akerlof, Covi and Rohring, 2017].

This paper reports on stakeholder focus groups conducted as part of a transdisciplinary research project, Ecological Effects of Sea Level Rise in the Northern Gulf of Mexico (EESLR-NGOM), to develop the project's communication products (such as "fact sheet" handouts and an informational website), scientific SLR planning models, and other decision-support tools (henceforth referred to as "tools") so they are relevant and readily usable for key regional stakeholders. EESLR-NGOM was a seven-year, United States National Oceanic and Atmospheric Administration (NOAA)-sponsored project [DeLorme et al., 2016; Kidwell et al., 2017] involving detailed assessments and process-based modeling to project the dynamic response of ecological habitats [Alizad et al., 2016], and future tide and hurricane storm surge and flooding potential under SLR scenarios along the northern U.S. Gulf [Bilskie et al., 2016; Passeri et al., 2016]. The focus groups were instrumental in fostering an atmosphere of dialogue that helped us understand the needs of stakeholders for information format, features, and functionality in order to better tailor communication towards these target audiences. Thus, this project serves as an example of how dialogue between scientists and stakeholders can be integrated into a long-term research project [Groffman et al., 2010].

Information about SLR and its projected effects on coastal communities is available on various subtopics, including physical science [Nicholls and Cazenave, 2010; Passeri et al., 2015; Bilskie et al., 2016], ecosystem response [Morris et al., 2002; Fagherazzi et al., 2012; Alizad et al., 2016], and economic impact and community resilience [e.g., Moser and Boykoff, 2013; Stephens, DeLorme and Hagen, 2016], and in various formats such as interactive map-based visualization tools [Stephens, DeLorme and Hagen, 2014]. Computer models in particular can aid decision-making by enabling audiences to explore "what if" scenarios based on available scientific knowledge [Addison et al., 2013]. For example, models can integrate SLR scenarios and potential restoration projects to assess feasibility and impacts at the regional and coastal-community scale. Nevertheless, challenges remain for making this information readily usable and relevant to stakeholders, including downscaling results of large-scale computer models to the community level [Dolan and Walker, 2006; Wang, Hagen and Alizad, 2013], incorporating local changes in coastline morphology [Plant, Thieler and Passeri, 2016], and understanding potential responses of coastal vegetation [Alizad et al., 2016]. Moreover, stakeholders require not just access to information, but support in 
incorporating it into their planning procedures and communication [Tribbia and Moser, 2008] as well as tools to help understand immediate risks and underlying physical, biological, and social processes [Stephens, DeLorme and Hagen, 2016].

Lemos, Kirchhoff and Ramprasad [2012] discuss the importance of transitioning useful to usable scientific information by recognizing the context wherein information will be used and recommending features, organization, and tools to support audiences' decision-making. They propose a framework for facilitating this transition: perception of fit (of information to audience needs), interplay (of new knowledge with other information sources audiences use), and interaction (between information producers and audiences). Availability, usability, salience, and source credibility can all form barriers to information use in adaptation planning [Heiskanen et al., 2007; Moser and Ekstrom, 2010; Moser and Dilling, 2011]. During communication design, interaction among scientists, communicators, and audiences is crucial to help all parties understand content and format needs [Pidgeon and Fischhoff, 2011], as shown in previous examples of environmental risk communication projects that have incorporated user-centered design [e.g., Lathrop et al., 2012; Morrow et al., 2015; Roth et al., 2017].

Another aspect of information design that improves communication is consideration of different dimensions of usability. Communicators should consider physical (ability to find information), cognitive (assisting with decision making), and affective (aesthetic arguments for using the information) dimensions of usability when designing documents or information systems [Carliner, 2000]. These dimensions have been shown to affect interpretation of SLR information by coastal residents [Covi and Kain, 2015] and coastal resource managers [Stephens, DeLorme and Hagen, 2015].

The purpose of our paper is to address the research question: How do stakeholders perceive their informational needs and uses regarding SLR communication and decision-support tools? The stakeholders in the EESLR-NGOM focus groups (resource managers, community planners, public officials, and environmental educators) represented the primary audiences for the scientific information produced by the project. Therefore, we use the term "stakeholder" when discussing this primary audience and "audience" when referring to all potential audiences (including the general public).

Method

In this project, focus groups were integral to improve communication and build trust among scientists and stakeholders and foster engagement and participatory decision-making [Addison et al., 2013]. The objectives were to gain insight and better understand stakeholders' SLR preparation experiences and operational and informational needs, solicit input on EESLR-NGOM's scientific tool development, learn to translate the project's research into readily-accessible and usable tools, generate outreach ideas, and collect feedback. We concentrate here on distilling stakeholders' communication and decision-support tool-related perceptions, expectations, and recommendations to address our study's research question.

Focus group interviewing can capture spontaneous comments, candid remarks, and diverse firsthand descriptions through group dynamics [Krueger and Casey, 2000; Stewart and Shamdasani, 2015] and is used to understand how various 
groups situate scientific issues within their own understandings [Hanson-Easey et al., 2015]. Key strengths of focus groups include potential to minimize researcher biases as participants respond in their own words [Eisenhauer and Nicholson, 2005], facilitating emergence of unplanned insights [Newig et al., 2008], and illuminating evolution of group understanding about a topic with repeated focus groups of returning participants [Morgan, Fellows and Guevara, 2008; Newig et al., 2008; Nind and Vinha, 2016]. Focus groups can foster high-level researcher-stakeholder interaction and enable participatory modeling to reduce the information usability gap [Lemos, Kirchhoff and Ramprasad, 2012], as well as help researchers understand stakeholder preferences for computer modeling assumptions [Jensen and Uddameri, 2009].

Six face-to-face focus groups of between eight and thirteen participants each and an overall total of 58 participants were conducted as part of EESLR-NGOM annual workshops (2011-2016) with the first being held in Year 1 of the project. The workshop agenda began with presentations on the current state of the scientific research and tool development. The project team of natural and social scientists and engineers provided overviews of the state-of-the-art in SLR impact assessments to a project advisory board of regional stakeholders (coastal resource managers and environmental education and communication specialists). The general content of the presentations, which varied year to year, always included communicating the project's objectives, status, and improvements based on stakeholders' feedback. Directly following the technical presentations, a purposive sample subset of workshop attendees (i.e., all regional stakeholders who were not scientists) convened privately to participate in the focus group. Group composition varied slightly each year, with fifteen participants contributing to two or more focus groups over the project duration.

An EESLR-NGOM social scientist, experienced in qualitative methods, moderated all groups except one in which she trained a science communicator to perform this role. Each group began with an introduction and explanation of objectives and procedures. The moderator then asked open-ended questions using a flexible interview guide [Berg and Lune, 2012]. Participant interaction was encouraged and the moderator listened actively, remained nonjudgmental, and asked occasional probing questions. Each group was audio-recorded with permission; had a research assistant taking notes, monitoring time, and managing logistics; and lasted about 90 minutes. All procedures were approved by the authors' Institutional Review Board. The interview guide, developed from team consultation and literature review, consisted of open-ended questions about SLR preparation, operational and informational needs, input on EESLR-NGOM tool development, and outreach ideas. It was pretested and remained relatively consistent each year.

Audio-recordings were transcribed in entirety by the science communicator and social scientist and double-checked for accuracy. The complete data set consisted of 158 transcript pages containing 67,347 overall total words and 33 additional pages of notes. The data was analyzed systematically within and across the groups (i.e., annually and cumulatively). The approach was interpretive and involved first listening to the audio-recordings and reading all transcripts and notes carefully. Next, unrestricted "open coding" was performed by selecting and labeling distinct units of meaning (sentences, phrases, and words) based on the interpreted relevance of the data such that categories were developed inductively and not 
How stakeholders plan to incorporate tools into their work

- Designing restoration projects

- Purchasing lands for habitat conservation

- Prioritizing ecological projects

- Defending proceeding with ecological projects
What features stakeholders perceive they need in order to make tools usable

- Appropriate simulation results

- Transparent assumptions

- Readily-understandable content and format

- Customization and interactive capabilities

- Multi-platform availability
How tools might be applied beyond stakeholders' immediate professional setting

- Ecologically-oriented SLR planning

- Commerciallyoriented SLR planning

- Community-oriented SLR planning

Figure 1. Three main themes derived from the study, with additional subthemes.

predetermined [Berg and Lune, 2012; Strauss and Corbin, 1998]. Then comparisons were made within and between the coded data to identify subcategories and relationships [Berg and Lune, 2012; Strauss and Corbin, 1998]. The social scientist shared preliminary results with the science communicator for possible further interpretation and refinement. This process produced some reordering of categories, introduced connections to frameworks in the literature that informed further analysis, and prompted improvements in wording used to label certain categories and themes. Agreement was readily reached that the presentation of findings was acceptable. The following section summarizes the findings.

Results and discussion
Overall, the study's findings reveal that the participants were concerned about SLR, believed planning was imperative and offered important insights, were optimistic about EESLR-NGOM's tools, and recommended a number of workable features. While various perspectives were represented, there was also much consensus. The results reflect three main themes, including: (1) how stakeholders plan to incorporate the tools into their work, (2) what features stakeholders perceive they need in order to make the tools usable, and (3) how the tools might be applied beyond the stakeholders' immediate professional setting. Themes and subthemes are illustrated in Figure 1 and expanded below. Representative participant quotations are presented in Tables 1-3.

\section{How stakeholders plan to incorporate the tools into their work}

Participants had favorable reactions to the communication products and decision-support tools being developed and expected they would have high utility for their own professional responsibilities involving SLR risk assessment and resource management. Various anticipated uses for the tools were discussed, encompassing interrelated ecological and social dimensions of SLR. While most SLR studies provide guidance for the year 2100, in multiple instances stakeholders indicated desire for their planning efforts on 50 years or less. A primary reason for the short-term focus was to make decisions that would impact within the span of their own career and lifetime. Analysis identified four major ways stakeholders anticipated incorporating the tools into their own SLR planning, including using scenarios for guidance on: (1) designing restoration projects, (2) purchasing lands 
Table 1. Representative quotations about how stakeholders plan to incorporate the tools into their work.

\begin{tabular}{|c|c|}
\hline Sub-theme & Representative quotation \\
\hline \multirow[t]{3}{*}{$\begin{array}{l}\text { Designing restoration } \\
\text { projects }\end{array}$} & $\begin{array}{l}\text { "I could potentially use it when planning a marsh enhancement } \\
\text { and restoration project in terms of figuring out design eleva- } \\
\text { tions... over the next fifty years." }\end{array}$ \\
\hline & $\begin{array}{l}\text { "Restoration... how to do it properly. How do I make sure that } \\
\text { a project is designed so it's sloped enough that it can handle } \\
\text { SLR... so something is still there fifty years from now." }\end{array}$ \\
\hline & $\begin{array}{l}\text { "Availability of areas for marsh to migrate... Having an infra- } \\
\text { structure that I might be wanting to look at relocating ten miles } \\
\text { away... Trying to understand... what changes might be made in } \\
\text { the future. How best to mitigate for those to try to maintain the } \\
\text { productivity of the area." }\end{array}$ \\
\hline \multirow[t]{2}{*}{$\begin{array}{l}\text { Purchasing lands for } \\
\text { habitat conservation }\end{array}$} & $\begin{array}{l}\text { "It's important to have tools so that we can understand for } \\
\text { conservation planning... If we can say that given a certain } \\
\text { scenario that we're going to see this much more inundation } \\
\text { upslope... and say we need to purchase these lands or this in- } \\
\text { frastructure is in danger... that's a definite use for a product that } \\
\text { would be derived from this kind of project." }\end{array}$ \\
\hline & $\begin{array}{l}\text { "The marsh modeling... would be a very helpful tool... knowing } \\
\text { where... infrastructure could restrict that habitat migra- } \\
\text { tion... would help me understand better where... conservation } \\
\text { would be best placed." }\end{array}$ \\
\hline $\begin{array}{l}\text { Prioritizing ecological } \\
\text { projects }\end{array}$ & $\begin{array}{l}\text { "Do I put my energy into Project A, B, or C?... Not only the de- } \\
\text { tails of one project, but the bigger scope. What areas... may be } \\
\text { more successful than others." }\end{array}$ \\
\hline \multirow[t]{2}{*}{$\begin{array}{l}\text { Defending proceeding } \\
\text { with ecological } \\
\text { projects }\end{array}$} & $\begin{array}{l}\text { "The accretion forecasting and the ability to make some predic- } \\
\text { tion of marsh behavior within a given scenario. I could apply } \\
\text { that, if not in the design of projects, at least in justification for } \\
\text { permits for projects." }\end{array}$ \\
\hline & $\begin{array}{l}\text { "Letting me know where to put my money and what projects } \\
\text { not to do. Not to give money to development if it's not going to } \\
\text { be there for very long." }\end{array}$ \\
\hline
\end{tabular}

for habitat conservation, (3) prioritizing ecological projects, and (4) defending ecological projects. Representative quotations appear in Table 1.

These results regarding stakeholders' own anticipated uses indicate high salience in perception of information fit for application in decision making. Salience has been defined as "information being relevant to the specific context in which the decision is made" [Liu et al., 2008]. Perception of information fit is important as it bolsters climate information usability [Lemos, Kirchhoff and Ramprasad, 2012].

\section{What features stakeholders perceive they need in order to make the tools usable}

The focus groups discussed general and specific features they perceived would be useful, beneficial, or important for the tools. Preferred features like information format and characteristics can be considered factors that influence users' perceptions of information fit, which influences usability [Lemos, Kirchhoff and Ramprasad, 2012]. Further, it has been acknowledged that usable information 
consists of three essential attributes: credibility (perception of information being dependable and high-quality), legitimacy (information being transparent and understandable), and salience [Liu et al., 2008]. Overall, participants desired accessible and accurate scientific evidence in a flexible format that would enable adjustments over time, across geographic domains, for multiple platforms, and for different levels of scientific knowledge and technical sophistication. Five preferred tool features were identified (appropriate simulation results, transparent assumptions, readily-understandable content and format, customization and interactive capabilities, and multi-platform availability), many of which align with essential attributes of usable information discussed in the literature. Each feature is described below, with representative quotations provided in Table 2 .

(1) Appropriate Simulation Results. According to participants, an essential feature for the tools was simulation of appropriate data. Specifically, five types of simulated data were identified: SLR rates and impacts, salinity projections, large-scale SLR simulations, and local results. Regarding the latter, participants preferred tools that included details in predicting SLR impacts at the "parcel-level" (i.e., individual tract of land) to guide community planners in infrastructure-related decision making. These results also demonstrate desire for accurate data and indicate credibility is crucial in these stakeholders' perceptions of information fit [Addison et al., 2013; Lindeman et al., 2015]. Further, the reported needs for local data suggest salience is also key in these stakeholders' perceptions of information fit for decision-making.

(2) Transparent Assumptions. The focus groups also thought making the scientists' assumptions about model limitations and uncertainty transparent to audiences was important. Explicit communication of assumptions was viewed as critical when downscaling model results for incorporation into local-scale tools. Two other features expected to help facilitate transparency included consistent scale bars and prominent source crediting. These preferences for displaying assumptions transparently are central to cognitive usability [Carliner, 2000] and support the idea that clearly communicating about complexity and uncertainty can improve model credibility [Addison et al., 2013].

(3) Readily-Understandable Content and Format. Additionally, participants thought tool content and formats should be readily understandable by audiences with different scientific expertise and technical knowledge levels. They advised information be presented straightforwardly. Five recommended features in this regard included: visualizations (especially maps), clear instructions, standardized explanations, context for usage, and case studies. Together, these results indicate translating and packaging the tools into readily-understandable content and formats would be effective in improving usability for heterogeneous audiences [Krantz, Monroe and Bartels, 2013].

(4) Customization and Interactive Capabilities. Customization has been defined as adjustments in design made at the end of the production process to meet an individual user's needs [Lemos, Kirchhoff and Ramprasad, 2012]. The focus groups thought customization was imperative for the tools being developed. Interactive capabilities that allow flexibility in user control over multiple combinations of features aid in customization. Four preferred interactive capabilities were identified, including: zooming and searching at varying 
levels of scale and technical detail for both the natural and built environments, adjusting scenario inputs (e.g., sediment quantities, time increments) to assess different influential factors on SLR variations, and comparisons with and connections to other tools. These results suggest developing interactive capabilities of the tools would be an effective customization strategy to improve usability.

(5) Multi-Platform Availability. For accessibility by various stakeholders, participants believed the tools should be available in multiple platforms (including online) without requiring special software. A related aspect of flexible data format was tool mobility and accessibility on laptops or tablets, potentially for use in the field. These findings indicate offering multi-platform availability would be another effective customization strategy [Lemos, Kirchhoff and Ramprasad, 2012], as well as addressing affective usability by serving needs for portable information [Carliner, 2000].

Table 2. Representative quotations about what features stakeholders perceive they need to make the tools usable.

\begin{tabular}{|c|c|}
\hline Features & Representative quotation \\
\hline \multirow[t]{5}{*}{$\begin{array}{l}\text { Appropriate } \\
\text { simulation results }\end{array}$} & $\begin{array}{l}\text { "Knowing the rate of sea level rise in each area... sedimentation } \\
\text { and the accretion... How fast the plants are going to grow and can } \\
\text { they outgrow sea level rise or not?" }\end{array}$ \\
\hline & $\begin{array}{l}\text { "Salinity projections over the next twenty-five years, or at least sa- } \\
\text { linity scenarios because if you're going to be investing three hun- } \\
\text { dred and fifty million dollars in restoration, you... would imagine } \\
\text { some of that's going to be on oyster reef restoration and to know } \\
\text { where you should site those." }\end{array}$ \\
\hline & $\begin{array}{l}\text { "Simulate sea level rise on larger scales in some natural systems... } \\
\text { where you can get better...biomass data, accretion data that they } \\
\text { can input into their models for the marshes." }\end{array}$ \\
\hline & $\begin{array}{l}\text { "Having accurate information that's locally-specific as far as the es- } \\
\text { timates of the sea level rise and how that's going to impact both the } \\
\text { natural and the built environment." }\end{array}$ \\
\hline & $\begin{array}{l}\text { "In making sure that it's usable for a planner in a community, you } \\
\text { need to be able to look at parcels... Not huge landscapes... That's } \\
\text { hard for them to translate and to make decisions about zones and } \\
\text { where XYZ infrastructures should be built to this level versus this } \\
\text { level." }\end{array}$ \\
\hline \multirow[t]{5}{*}{$\begin{array}{l}\text { Transparent } \\
\text { assumptions }\end{array}$} & $\begin{array}{l}\text { "Some kind of product that discusses the limitations and assump- } \\
\text { tions and errors that are in these models." }\end{array}$ \\
\hline & $\begin{array}{l}\text { "Explain that error in that description... It's much easier to inter- } \\
\text { pret it properly." }\end{array}$ \\
\hline & "Include the level of certainty that we have on these predictions." \\
\hline & $\begin{array}{l}\text { "Taking it from that larger scale, paring it down on to maybe the } \\
\text { project size... making it clear to the users that we're either very con- } \\
\text { fident, or we're kind of confident, or we're just throwing a dart at a } \\
\text { dartboard confident." }\end{array}$ \\
\hline & $\begin{array}{l}\text { "What limitations there might be as you downscale a model to the } \\
\text { parcel level." }\end{array}$ \\
\hline
\end{tabular}


Table 2. Continued from the previous page.

\begin{tabular}{|c|c|}
\hline Features & Representative quotation \\
\hline & $\begin{array}{l}\text { "Looking at a bunch of the maps, when the scale bar was differ- } \\
\text { ent for every single map... it was really hard to compare between } \\
\text { maps... If the scale bar was just consistent... you'd totally be able } \\
\text { to see... what the patterns were." }\end{array}$ \\
\hline & $\begin{array}{l}\text { "Have right on that graphic... its reference so that I didn't have to } \\
\text { look at that and say...'Where did I get that? And who should I } \\
\text { credit for this?'... That would make it very easy to grab those tools } \\
\text { and use them." }\end{array}$ \\
\hline \multirow{4}{*}{$\begin{array}{l}\text { Readily- } \\
\text { understandable } \\
\text { content and } \\
\text { format }\end{array}$} & $\begin{array}{l}\text { "Tools that are simple that you can take to a local planning commis- } \\
\text { sion... The science... needs to be translated to the local population, } \\
\text { the local elected officials in an easy format." }\end{array}$ \\
\hline & $\begin{array}{l}\text { "A coastal sensitivity map... locally specific that... gives you some- } \\
\text { thing like low, medium, and high vulnerability to sea level rise, } \\
\text { and...the sensitivity of the built environment... the natural envir- } \\
\text { onment... with kinds of icons... you could take it to anybody to } \\
\text { use." }\end{array}$ \\
\hline & $\begin{array}{l}\text { "Really good instructions on how to use the tools... that you don't } \\
\text { need a mentor or someone standing alongside you to teach you to } \\
\text { use the tool." }\end{array}$ \\
\hline & $\begin{array}{l}\text { "A tool that's already packaged appropriately for a certain } \\
\text { level... More than just the graphic but... the context in which to use } \\
\text { it." }\end{array}$ \\
\hline \multirow[t]{5}{*}{$\begin{array}{l}\text { Customization } \\
\text { and interactive } \\
\text { capabilities }\end{array}$} & $\begin{array}{l}\text { "Your audiences are all going to want different things to put on top } \\
\text { of it. So it just needs to be... accessible in a way that they can do } \\
\text { that for that community." }\end{array}$ \\
\hline & $\begin{array}{l}\text { "Have a dozen good case studies... utilizing the tool... where } \\
\text { maybe I want to look at how my barrier islands might be chan- } \\
\text { ging, or this inlet closes or opens, and how that impacts my area. } \\
\text {... How certain coastal habitats are expanding or contracting with } \\
\text { sea level rise." }\end{array}$ \\
\hline & $\begin{array}{l}\text { "Zooming in and looking at some better details... like beaches for } \\
\text { nesting sea turtles or shorebirds. Maybe we want to focus in on } \\
\text { that type of habitat and specifically look at how sea level rise may } \\
\text { be affecting those species and those habitats." }\end{array}$ \\
\hline & $\begin{array}{l}\text { "You have to know... what you've got coming in... Your models are } \\
\text { real different depending on whether or not you're going to get slow } \\
\text { or fast sea level rise and whether there's a lot of sediment there or } \\
\text { not." }\end{array}$ \\
\hline & $\begin{array}{l}\text { "To be able... to compare the exact the same scenario... that's of } \\
\text { enormous value... for resource managers... because when we de- } \\
\text { cide that we have to run a model for a particular area later... we'll } \\
\text { have a little bit more capability to select a model that we want to } \\
\text { run." }\end{array}$ \\
\hline \multirow[t]{2}{*}{$\begin{array}{l}\text { Multi-platform } \\
\text { availability }\end{array}$} & $\begin{array}{l}\text { "Useable across different platforms... Something that works } \\
\text { equally well on my laptop or on my iPad." }\end{array}$ \\
\hline & "It's got to be transportable." \\
\hline
\end{tabular}


How the tools could be applied in broader contexts beyond EESLR-NGOM's scope and participants' own resource management responsibilities was a third theme in the focus group discussions. Participants were optimistic about tool adoption by other audiences (e.g., local officials, developers, community planners, general public) involved in social and ecological SLR planning. Several expected uses for the tools by others were identified. These include more precise and convincing SLR communication and decision support for: (1) ecologically-oriented SLR planning (such as that of EESLR-NGOM) including purchasing lands for habitat conservation, prioritizing projects, and justifying projects, (2) commercially-oriented SLR planning, especially for fishing-related industries, and (3) community-oriented SLR planning including critical infrastructure placement (e.g., emergency management, sewer treatment plants), development strategies, and related policy-making and actionable preparation. Representative quotations appear in Table 3. The finding that participants perceived much potential for tool application beyond EESLR-NGOM's scope suggests the products are perceived as able to interplay with other existing tools. Whether and how well new information can interplay with existing information sources affects usability [Lemos, Kirchhoff and Ramprasad, 2012] and application to purposes beyond the immediate scope of a project.

\section{Study implications}

This study illustrates how scientist-stakeholder dialogue can be incorporated as part of communication efforts within a broader research project. The findings presented here contribute to an in-depth understanding of stakeholders' perceptions of their anticipated uses of and desired features for the EESLR-NGOM communication products and tools. There was also an expressed desire to focus on the short-term (i.e., the next 50 years) as opposed to generations in the future (e.g., Year 2100). Participants expected these products would have high utility and serve a dual purpose: (1) provide accurate, scientific, place-based SLR ecological data in a flexible format to guide design and prioritization of SLR planning projects for the natural and built environments and (2) provide an accessible, credible, data-driven, multi-platform communications tool about SLR and EESLR-NGOM to convince and support diverse audiences to take actionable preparation. Both purposes were furthered by repeated focus groups, a social science method enabling meaningful stakeholder feedback.

Research on the usability of technical communication tools is audience- and context-dependent, and often requires long-term interaction with target audiences in order to understand their particular needs [Shneiderman and Plaisant, 2006]. While the specific results reported here may not, therefore, be generalizable to all other contexts, lessons learned may inform design of similar environmental communication products and decision-support tools. This paper demonstrates how a social science-based focus group approach can foster constructive communication of science within a broader research context, as recommended in the literature [Pidgeon and Fischhoff, 2011]. In particular, we demonstrate how a dialogic approach can help developers better understand stakeholders' perceived needs and uses for SLR decision-support tools. Consequently, we believe our study's findings transcend EESLR-NGOM and can well serve other related science communication efforts. 
Table 3. Representative quotations about how tools might be applied beyond the stakeholders' immediate professional setting.

\begin{tabular}{|c|c|}
\hline Sub-theme & Representative quotation \\
\hline \multirow{3}{*}{$\begin{array}{l}\text { Ecologically- } \\
\text { oriented SLR } \\
\text { planning }\end{array}$} & $\begin{array}{l}\text { "Tools that help communities plan to set aside areas where habitat } \\
\text { can migrate." }\end{array}$ \\
\hline & $\begin{array}{l}\text { "The habitat suitability mapping... if those things can be accurate } \\
\text { and then you can lay on top of that projections of sea level rise, } \\
\text { that does have a lot of power... You can take certain priorities in } \\
\text { terms of conservation issues - which areas to protect, which areas } \\
\text { to restore." }\end{array}$ \\
\hline & $\begin{array}{l}\text { "It can help in terms of prioritizing "where do you want to } \\
\text { put your energy and bucks first," what's the best use of the } \\
\text { money?... There's habitat protection in the form of easements and } \\
\text { purchasing properties upslope, moving infrastructure... Would } \\
\text { it be a better use than a beach re-nourishment or a living } \\
\text { shoreline?... These tools could be very important for that." }\end{array}$ \\
\hline $\begin{array}{l}\text { Commercially- } \\
\text { oriented SLR } \\
\text { planning }\end{array}$ & $\begin{array}{l}\text { "The oyster industry... some of the predictions that come from this } \\
\text { work could help how those resources are going to respond in the } \\
\text { future... are we going to see fewer oyster beds?... are they going to } \\
\text { be moving?" }\end{array}$ \\
\hline \multirow[t]{4}{*}{$\begin{array}{l}\text { Community- } \\
\text { oriented SLR } \\
\text { planning }\end{array}$} & $\begin{array}{l}\text { "Land use/land cover projections... would be of great interest to } \\
\text { groups like in coastal Mississippi... for where they want to move, } \\
\text { where they want to put in new roads... and how they want to de- } \\
\text { velop... long term." }\end{array}$ \\
\hline & $\begin{array}{l}\text { "It's going to give a lot more scientific foundation... when you're } \\
\text { having to... go forth for people to make policy and all that. You } \\
\text { can do that with a little more certainty." }\end{array}$ \\
\hline & $\begin{array}{l}\text { "Trying to get the public to really think ahead.... is critical. Hav- } \\
\text { ing the scientific information to present the models to the pub- } \\
\text { lic... would help." }\end{array}$ \\
\hline & $\begin{array}{l}\text { "We need an accurate picture ourselves before we can go forward } \\
\text { and put that out to the public... I think one of the outputs we're } \\
\text { going to see in the EESLR process is to get another step closer to } \\
\text { the refinement of those models and scientific approaches." }\end{array}$ \\
\hline
\end{tabular}

It was expected that the focus groups would yield insights about how stakeholders plan to incorporate the tools into their work and what features stakeholders perceive they need to make the tools usable. However, the third theme, how tools might be applied beyond the stakeholders' immediate professional setting, was rather surprising. We had not anticipated the degree to which stakeholders envisioned using the tools for certain applications (e.g., public outreach to communities particularly vulnerable to SLR). Thus, the focus groups helped the team better understand how the stakeholders perceived the tools fitting into their broader contexts of understanding, communicating about, and responding to risks [Granderson, 2014].

Additionally, this paper demonstrates some benefits of qualitative social science methods for developing environmental and risk communication projects. Focus groups have strengths (e.g., flexibility, inclusivity) that fostered dialogue among participants and generated a variety of potential uses and recommended features for the SLR communication products and planning tools from participants' 
viewpoints and experiences. Through this process, the team gained insights into context that are less likely to emerge through other approaches. Further, stakeholders were able to interact directly and repeatedly with information producers so the tools were developed in ways that were accessible and readily useable for them. This type of legitimate two-way interaction can build trust and enable co-production of usable information and tools [Heiskanen et al., 2007; Lemos, Kirchhoff and Ramprasad, 2012], build consensus among different interest groups on the need for action [Frazier, Wood and Yarnal, 2010], and contribute to project sustainability [Servaes, 2016]. It is particularly important in promoting technology acceptance by decision-makers [Addison et al., 2013] and other end-users [Trigg and Roy, 2007].

The focus group results assisted the EESLR-NGOM team in identifying key physical (navigability that assists in finding information), cognitive (assisting with decision-making), and affective (aesthetic) elements of usability [Carliner, 2000]. Each element influences audiences' perception of fit of the information to their needs as well as the team's understanding of how project results would interplay with other information sources that audiences already use [Lemos, Kirchhoff and Ramprasad, 2012]. For example, participants made comparisons between the EESLR-NGOM computer models and those underpinning other SLR visualization tools, and discussed how the new research results might be linked to information they use for management originating from other institutions in the region. Participants described the vast array of alternate models and tools they have at their disposal, which led to recognition that any new models, tools, and data produced must fit into that overall paradigm and add value to what already exists.

Participants also anticipated certain uses for the project products that the team had not considered primary (e.g., public outreach) and discussed ways the products could inform more effective locally-situated SLR messaging [Schweizer et al., 2009]. Through the project process, the EESLR-NGOM team came to a better understanding of the individual perspectives and contexts in which stakeholders would use scientific information. Therefore, what the team recognized as "usable" information and tools shifted in response to stakeholders' perceived needs, and enabled better customization of communication products and strategies [Longnecker, 2016]. This illustrates a benefit of adopting a dialogic model of science communication, in which anticipated tool uses are not constrained by the preconceptions of the project scientists [Bucchi, 2008, pp. 75-76].

The results suggested another key consideration for stakeholder engagement in projects that involve computer modeling of geophysical and ecological dynamics and decision-support tools development. We found it was important to distinguish between the computer models and the associated visualization tools and other products that communicate the results of those models. While the risk communication literature argues for stakeholder participation in development of conceptual models about risk [e.g., Morgan et al., 2002], such participation is generally used to develop products that communicate the results of computer models rather than making changes to the models themselves [e.g., Lathrop et al., 2012; Roth et al., 2017; but see Jensen and Uddameri, 2009]. We found it necessary to clarify for stakeholders the distinction between the biogeophysics-based computer models that underlie the EESLR-NGOM project and the map-based visualization tool that enables users to explore results from the computer models. 
The focus groups, comprised of end-users, were intended to obtain feedback to make the decision-support tools and datasets usable for end-users rather than acquire feedback on the underlying computer models. It is noteworthy, however, that stakeholders provided valuable information that was also used to improve model inputs and validation by apprising the team of additional data sources [Stephens, DeLorme and Hagen, 2015]. Previous research has demonstrated that a dialogic communication can illuminate deficiencies in scientific models through practical experience, for example, in communication about radiation risks to English farmers [Wynne, 1989].

\section{Future research recommendations}

More research is needed to examine stakeholder perspectives in projects aimed to develop or improve localized environmental risk communication products and targeted decision-support tools [Moser and Dilling, 2011]. Future studies gathering participants' input, especially via qualitative methods, would be beneficial for comparative and evaluative purposes. We recommend, in particular, that projects, including biogeophysical research projects (such as EESLR-NGOM), be open to feedback from non-specialist project participants, which can be fostered effectively with focus groups. As our experience confirms, the dialogue that ensues during these interactions is valuable to both researchers and participants for building trust and improving risk communication. However, we also note the importance of scientists recognizing the applied expertise of stakeholders [Suldovsky, McGreavy and Lindenfeld, 2017] and attention to the overall interaction dynamics [Phillips, 2011] for creating legitimate dialogue.

It is recognized that researchers must balance keeping complex tools simple enough for wide application and distribution for diverse audiences [van Aalst, Cannon and Burton, 2008]. This paper reports on efforts to engage with specific target audiences for the purpose of public communication of scientific results in formats that are useful and usable for these audiences. As such, we did not engage with the broader lay public in the project region about the risks associated with SLR. Further research on how the lay public may interpret and respond to communication tools, particularly web-based resources, would be valuable. Additionally, research on needs of the lay public, in addition to specialist stakeholder groups, for scientific information about SLR is recommended [Akerlof, Covi and Rohring, 2017; Lindenfeld et al., 2012]. Nonetheless, this project demonstrates that place-based, scientific, and non-specialized knowledge can be integrated to build trust, better understand the complex processes, and provide value to the appropriateness of potential tools to solve local problems.

Acknowledgments This research was funded in part under awards NA10NOS4780146 and NA16NOS4780208 from the National Oceanic and Atmospheric Administration (NOAA) Center for Sponsored Coastal Ocean Research and the Louisiana Sea Grant Laborde Chair. The authors wish to thank management and staff of the Apalachicola, Grand Bay, and Weeks Bay National Estuarine Research Reserves as well as the NOAA Office of Coastal Management. 
Addison, P. F. E., Rumpff, L., Bau, S. S., Carey, J. M., Chee, Y. E., Jarrad, F. C., McBride, M. F. and Burgman, M. A. (2013). 'Practical solutions for making models indispensable in conservation decision-making'. Diversity and Distributions 19 (5-6), pp. 490-502. https : //doi.org/10.1111/ddi.12054.

Akerlof, K., Covi, M. and Rohring, E. (2017). 'Communicating sea level rise'. In: Oxford research encyclopedia of climate science. New York, U.S.A.: Oxford University Press. https://doi.org/10.1093/acrefore/9780190228620.013.417.

Alizad, K., Hagen, S. C., Morris, J. T., Medeiros, S. C., Bilskie, M. V. and Weishampel, J. F. (2016). 'Coastal wetland response to sea-level rise in a fluvial estuarine system'. Earth's Future 4 (11), pp. 483-497. https://doi.org/10.1002/2016ef000385.

Berg, B. L. and Lune, H. (2012). Qualitative research methods for the social sciences. Boston, MA, U.S.A.: Pearson.

Bilskie, M. V., Hagen, S. C., Alizad, K., Medeiros, S. C., Passeri, D. L., Needham, H. F. and Cox, A. (2016). 'Dynamic simulation and numerical analysis of hurricane storm surge under sea level rise with geomorphologic changes along the northern Gulf of Mexico'. Earth's Future 4 (5), pp. 177-193. https://doi.org/10.1002/2015ef000347.

Bucchi, M. (2008). 'Of deficits, deviations and dialogues: theories of public communication of science'. In: Handbook of Public Communication of Science and Technology. Ed. by M. Bucchi and B. Trench. London, U.K. and New York, U.S.A.: Routledge, pp. 57-76.

Carliner, S. (2000). 'Physical, cognitive and affective: a three-part framework for information design'. Technical Communication 47 (4), pp. 561-576.

Covi, M. P. and Kain, D. J. (2015). 'Sea-level rise risk communication: public understanding, risk perception and attitudes about information'. Environmental Communication 10 (5), pp. 612-633. https://doi.org/10.1080/17524032.2015.1056541.

DeLorme, D. E., Kidwell, D., Hagen, S. C. and Stephens, S. H. (2016). 'Developing and managing transdisciplinary and transformative research on the coastal dynamics of sea level rise: Experiences and lessons learned'. Earth's Future 4 (5), pp. 194-209. https://doi.org/10.1002/2015ef000346.

Dolan, A. H. and Walker, I. J. (2006). 'Understanding vulnerability of coastal communities to climate change related risks'. Journal of Coastal Research 39 (SI), pp. 1316-1323. URL: https: //www. jstor.org/stable/25742967.

Eisenhauer, B. W. and Nicholson, B. (2005). 'Using stakeholders' views: a social science methodology for the inclusive design of environmental communications'. Applied Environmental Education $\mathcal{E}$ Communication 4 (1), pp. 19-30. https://doi.org/10.1080/15330150590910701.

Fagherazzi, S., Kirwan, M. L., Mudd, S. M., Guntenspergen, G. R., Temmerman, S., D’Alpaos, A., van de Koppel, J., Rybczyk, J. M., Reyes, E., Craft, C. and Clough, J. (2012). 'Numerical models of salt marsh evolution: ecological, geomorphic and climatic factors'. Reviews of Geophysics 50 (1), RG1002. https://doi.org/10.1029/2011RG000359.

Frazier, T. G., Wood, N. and Yarnal, B. (2010). 'Stakeholder perspectives on land-use strategies for adapting to climate-change-enhanced coastal hazards: Sarasota, Florida'. Applied Geography 30 (4), pp. 506-517. https://doi.org/10.1016/j.apgeog.2010.05.007.

Granderson, A. A. (2014). 'Making sense of climate change risks and responses at the community level: a cultural-political lens'. Climate Risk Management 3, pp. 55-64.https://doi.org/10.1016/j.crm.2014.05.003. 
Groffman, P. M., Stylinski, C., Nisbet, M. C., Duarte, C. M., Jordan, R., Burgin, A., Previtali, M. A. and Coloso, J. (2010). 'Restarting the conversation: challenges at the interface between ecology and society'. Frontiers in Ecology and the Environment 8 (6), pp. 284-291. https://doi.org/10.1890/090160.

Hanson-Easey, S., Williams, S., Hansen, A., Fogarty, K. and Bi, P. (2015). 'Speaking of climate change: a discursive analysis of lay understandings'. Science Communication 37 (2), pp. 217-239. https://doi.org/10.1177/1075547014568418.

Heiskanen, E., Timonen, P., Nissinen, A., Grönroos, J., Honkanen, A., Katajajuuri, J.-M., Kettunen, J., Kurppa, S., Mäkinen, T., Seppälä, J., Silvenius, F., Virtanen, Y. and Voutilainen, P. (2007). 'Developing a benchmark tool for sustainable consumption: an iterative process'. Applied Environmental Education \& Communication 6 (2), pp. 127-137. https://doi.org/10.1080/15330150701598163.

Jensen, R. and Uddameri, V. (2009). 'Using communication research to gather stakeholder preferences to improve groundwater management models: a South Texas case study'. JCOM 08 (1), A02. URL: https://jcom.sissa.it/archive/08/01/Jcom0801(2009)A02.

Kidwell, D. M., Dietrich, J. C., Hagen, S. C. and Medeiros, S. C. (2017). 'An Earth's Future Special Collection: Impacts of the coastal dynamics of sea level rise on low-gradient coastal landscapes'. Earth's Future 5 (1), pp. 2-9. https://doi.org/10.1002/2016ef000493.

Krantz, S., Monroe, M. and Bartels, W.-L. (2013). 'Creating extension programs for change: forest landowners and climate change communication'. Applied Environmental Education E Communication 12 (4), pp. 272-279. https://doi.org/10.1080/1533015x.2013.876305.

Krueger, R. A. and Casey, M. A. (2000). Focus groups: a practical guide for applied research. Thousand Oaks, CA, U.S.A.: Sage.

Lathrop, R. G., Auermuller, L., Haag, S. and Im, W. (2012). 'The StormWater Management and Planning Tool: coastal water quality enhancement through the use of an internet-based geospatial tool'. Coastal Management 40 (4), pp. 339-354. https://doi.org/10.1080/08920753.2012.692309.

Lemos, M. C., Kirchhoff, C. J. and Ramprasad, V. (2012). 'Narrowing the climate information usability gap'. Nature Climate Change 2 (11), pp. 789-794. https://doi.org/10.1038/nclimate1614.

Leon, J. X., Hardcastle, J., James, R., Albert, S., Kereseka, J. and Woodroffe, C. D. (2015). 'Supporting local and traditional knowledge with science for adaptation to climate change: lessons learned from participatory three-dimensional modeling in BoeBoe, Solomon islands'. Coastal Management 43 (4), pp. 424-438. https://doi.org/10.1080/08920753.2015.1046808.

Lindeman, K. C., Dame, L. E., Avenarius, C. B., Horton, B. P., Donnelly, J. P., Corbett, D. R., Kemp, A. C., Lane, P., Mann, M. E. and Peltier, W. R. (2015). 'Science needs for sea-level adaptation planning: comparisons among three U.S. atlantic coastal regions'. Coastal Management 43 (5), pp. 555-574. https://doi.org/10.1080/08920753.2015.1075282.

Lindenfeld, L. A., Hall, D. M., McGreavy, B., Silka, L. and Hart, D. (2012). ‘Creating a place for environmental communication research in sustainability science'. Environmental Communication 6 (1), pp. 23-43. https://doi.org/10.1080/17524032.2011.640702.

Liu, Y., Gupta, H., Springer, E. and Wagener, T. (2008). 'Linking science with environmental decision making: experiences from an integrated modeling approach to supporting sustainable water resources management'. Environmental Modelling \& Software 23 (7), pp. 846-858. https://doi.org/10.1016/j. envsoft.2007.10.007. 
Longnecker, N. (2016). 'An integrated model of science communication - More than providing evidence'. JCOM 15 (05), Y01.

URL: https://jcom.sissa.it/archive/15/05/JCOM_1505_2016_Y01.

Morgan, D., Fellows, C. and Guevara, H. (2008). 'Emergent approaches to focus group research'. In: Handbook of emergent methods. Ed. by H.-B. S. N. and P. Leavy. New York, U.S.A.: Guilford, pp. 189-205.

Morgan, M. G., Fischhoff, B., Bostrom, A. and Atman, C. J. (2002). Risk Communication: a mental models approach. New York, U.S.A.: Cambridge University Press. https://doi .org/10.1017/CB09780511814679.

Morris, J. T., Sundareshwar, P. V., Nietch, C. T., Kjerfve, B. and Cahoon, D. R. (2002). 'Responses of coastal wetlands to rising sea level'. Ecology 83 (10), pp. 2869-2877. https://doi.org/10.1890/0012-9658(2002)083[2869:rocwtr]2.0.co;2.

Morrow, B. H., Lazo, J. K., Rhome, J. and Feyen, J. (2015). 'Improving storm surge risk communication: stakeholder perspectives'. Bulletin of the American Meteorological Society 96 (1), pp. 35-48. https://doi.org/10.1175/bams-d-13-00197.1.

Moser, S. C. and Ekstrom, J. A. (2010). 'A framework to diagnose barriers to climate change adaptation'. Proceedings of the National Academy of Sciences 107 (51), pp. 22026-22031. https://doi.org/10.1073/pnas. 1007887107.

Moser, S. C. and Boykoff, M. T. (2013). Successful adaptation to climate change: linking science and policy in a rapidly changing world. New York, U.S.A.: Routledge. https://doi.org/10.4324/9780203593882.

Moser, S. C. and Dilling, L. (2011). 'Communicating climate change: closing the science-action gap'. In: The Oxford Handbook of Climate Change and Society. Ed. by J. S. Dryzek, R. B. Norgaard and D. Schlosberg. Oxford, U.K.: Oxford University Press. https://doi.org/10.1093/oxfordhb/9780199566600.003.0011.

National Academies of Sciences, Engineering, and Medicine (2017). Communicating Science Effectively: A Research Agenda. Washington, DC, U.S.A.: National Academies Press. https://doi .org/10.17226/23674.

Newig, J., Gaube, V., Berkhoff, K., Kaldrack, K., Kastens, B., Lutz, J., Schlußmeier, B., Adensam, H. and Haberl, H. (2008). 'The role of formalisation, participation and context in the success of public involvement mechanisms in resource management'. Systemic Practice and Action Research 21 (6), pp. 423-441. https://doi.org/10.1007/s11213-008-9113-9.

Nicholls, R. J. and Cazenave, A. (2010). 'Sea-level rise and its impact on coastal zones'. Science 328 (5985), pp. 1517-1520. https://doi.org/10.1126/science.1185782.

Nind, M. and Vinha, H. (2016). 'Creative interactions with data: using visual and metaphorical devices in repeated focus groups'. Qualitative Research 16 (1), pp. 9-26. https://doi.org/10.1177/1468794114557993.

Passeri, D. L., Hagen, S. C., Medeiros, S. C., Bilskie, M. V., Alizad, K. and Wang, D. (2015). 'The dynamic effects of sea level rise on low-gradient coastal landscapes: a review'. Earth's Future 3 (6), pp. 159-181. https://doi.org/10.1002/2015ef000298.

Passeri, D. L., Hagen, S. C., Plant, N. G., Bilskie, M. V., Medeiros, S. C. and Alizad, K. (2016). 'Tidal hydrodynamics under future sea level rise and coastal morphology in the Northern Gulf of Mexico'. Earth's Future 4 (5), pp. 159-176. https://doi.org/10.1002/2015ef000332.

Phillips, L. J. (2011). 'Analysing the dialogic turn in the communication of research-based knowledge: an exploration of the tensions in collaborative research'. Public Understanding of Science 20 (1), pp. 80-100. https://doi.org/10.1177/0963662509340092. 
Pidgeon, N. and Fischhoff, B. (2011). 'The role of social and decision sciences in communicating uncertain climate risks'. Nature Climate Change 1 (1), pp. 35-41. https://doi.org/10.1038/nclimate1080.

Plant, N. G., Thieler, E. R. and Passeri, D. L. (2016). 'Coupling centennial-scale shoreline change to sea-level rise and coastal morphology in the gulf of Mexico using a Bayesian network'. Earth's Future 4 (5), pp. 143-158.

https://doi.org/10.1002/2015ef000331.

Roth, R. E., Hart, D., Mead, R. and Quinn, C. (2017). 'Wireframing for interactive \& web-based geographic visualization: designing the NOAA Lake Level Viewer'. Cartography and Geographic Information Science 44 (4), pp. 338-357. https://doi.org/10.1080/15230406.2016.1171166.

Schweizer, S., Thompson, J. L., Teel, T. and Bruyere, B. (2009). 'Strategies for communicating about climate change impacts on public lands'. Science Communication 31 (2), pp. 266-274. https://doi.org/10.1177/1075547009352971.

Servaes, J. (2016). 'How 'sustainable' is development communication research?' International Communication Gazette 78 (7), pp. 701-710. https://doi.org/10.1177/1748048516655732.

Sheppard, S. R. J., Shaw, A., Flanders, D., Burch, S., Wiek, A., Carmichael, J., Robinson, J. and Cohen, S. (2011). 'Future visioning of local climate change: a framework for community engagement and planning with scenarios and visualisation'. Futures 43 (4), pp. 400-412. https://doi.org/10.1016/j.futures.2011.01.009.

Shneiderman, B. and Plaisant, C. (2006). 'Strategies for evaluating information visualization tools: multi-dimensional in-depth long-term case studies'. In: Proceedings of the 2006 AVI workshop on beyond time and errors novel evaluation methods for information visualization - BELIV'06, pp. 1-7. https://doi.org/10.1145/1168149.1168158.

Stephens, S. H., DeLorme, D. E. and Hagen, S. C. (2014). 'An Analysis of the Narrative-Building Features of Interactive Sea Level Rise Viewers'. Science Communication 36 (6), pp. 675-705. https://doi.org/10.1177/1075547014550371.

- (2015). 'Evaluating the Utility and Communicative Effectiveness of an Interactive Sea-Level Rise Viewer Through Stakeholder Engagement'. Journal of Business and Technical Communication 29 (3), pp. 314-343. https://doi.org/10.1177/1050651915573963.

- (2016). 'Evaluation of the Design Features of Interactive Sea-Level Rise Viewers for Risk Communication'. Environmental Communication 11 (2), pp. 248-262. https://doi.org/10.1080/17524032.2016.1167758.

Stewart, D. W. and Shamdasani, P. N. (2015). Focus groups: theory and practice. Los Angeles, U.S.A.: SAGE.

Strauss, A. and Corbin, J. (1998). ‘Basics of qualitative research: grounded theory procedures and techniques'.

Suldovsky, B., McGreavy, B. and Lindenfeld, L. (2017). 'Science communication and stakeholder expertise: insights from sustainability science'. Environmental Communication 11 (5), pp. 587-592. https://doi.org/10.1080/17524032.2017.1308408.

Tribbia, J. and Moser, S. C. (2008). 'More than information: what coastal managers need to plan for climate change'. Environmental Science $\mathcal{E}$ Policy 11 (4), pp. 315-328. https://doi.org/10.1016/j.envsci.2008.01.003.

Trigg, S. N. and Roy, D. P. (2007). 'A focus group study of factors that promote and constrain the use of satellite-derived fire products by resource managers in southern Africa'. Journal of Environmental Management 82 (1), pp. 95-110. https://doi.org/10.1016/j.jenvman.2005.12.008. 
van Aalst, M. K., Cannon, T. and Burton, I. (2008). 'Community level adaptation to climate change: the potential role of participatory community risk assessment'. Global Environmental Change 18 (1), pp. 165-179. https://doi.org/10.1016/j.gloenvcha.2007.06.002.

Wang, D., Hagen, S. C. and Alizad, K. (2013). 'Climate change impact and uncertainty analysis of extreme rainfall events in the Apalachicola river basin, Florida'. Journal of Hydrology 480, pp. 125-135. https://doi.org/10.1016/j.jhydrol.2012.12.015.

Wynne, B. (1989). 'Sheepfarming after Chernobyl: a case study in communicating scientific information'. Environment: Science and Policy for Sustainable Development 31 (2), pp. 10-39. https://doi.org/10.1080/00139157.1989.9928930.

Authors

\section{How to cite}

(C) The Author(s). This article is licensed under the terms of the Creative Commons Attribution - NonCommercial - NoDerivativeWorks 4.0 License. ISSN 1824-2049. Published by SISSA Medialab. jcom.sissa.it
Denise E. DeLorme is a Professor of Environmental Communication in the Department of Environmental Sciences, Louisiana State University (LSU). Her current research interests include environmental and science communication, stakeholder engagement, and social marketing. E-mail: ddelorme@lsu.edu.

Sonia H. Stephens is an Assistant Professor of Technical Communication in the Department of English at the University of Central Florida. Her research examines scientific communication in digital and visual media, visual risk communication, and user-centered design. E-mail: sonia.stephens@ucf.edu.

Scott C. Hagen is a LSU Professor of Civil \& Environmental Engineering with a joint appointment in the Center for Computation \& Technology and serves as director of the Center for Coastal Resiliency. He holds the Louisiana Sea Grant Laborde Chair and is a Fellow of ASCE. His primary research focus is on tide, storm surge and ecological modeling of the coastal dynamics of sea level rise and is aiding coastal planners along the gulf and east coasts of the U.S.

E-mail: shagen@lsu.edu.

Matthew V. Bilskie is a Research Scientist at the Center for Coastal Resiliency, LSU. His research focuses on numerical modeling of coastal and estuarine processes (tide, wind-wave, and hurricane storm surge) for present day and under climate change scenarios. E-mail: mbilsk3@lsu.edu.

DeLorme, D. E., Stephens, S. E., Hagen, S. C. and Bilskie, M. V. (2018).

'Communicating with Coastal Decision-Makers and Environmental Educators via Sea Level Rise Decision-Support Tools'. JCOM 17 (03), A03. https://doi.org/10.22323/2.17030203. 